\title{
Word Made Flesh: Czech Women's Writing from Communism to Post-Communism
}

M A D ELA IN E HRON

In the beginning was the Word, and the Word was with God, and the Word was God... And the Word became flesh and lived among us... (John 1:1; 1:14 NRSV)

I begin with a rather "revelationary" quote because my endeavor in this essay may appear rather apocryphal: I will attempt a synoptic account of the transition of Czech women's fiction from communism to post-communism. Given the diversity of Czech authors in this period, and more importantly, the difficulty of defining a body of "Czech women's writing" within this corpus, I can only offer you a parabolic parable - that Czech women's fiction transfigured in the shift from communism to post communism from "word to flesh."

The bare-bone skeleton of my argument may be structured thus: in communism, language, both in its oppressive and resistant forms, established the Word as the paradigm defining both the Czech governing economy and the resistant literary economy - "the Word was God." Moreover, this Word, both in its totalizing, totalitarian communalism and its dissident denunciation advocating universal human rights, formulated itself in collective and generic terms. Conversely, in post-communism, "the Word became Flesh": the shift to a market economy, private property and democracy favored a turn to individualism, material concerns, and emphasis on the body - materializing the former symbolic abstractions into localized, individualized particularity. Fleshing out how Czech women's literature is gendered in these two different political systems might be summarized thus: in communism, women were "incarcerated" by the word; their gendered, individual concerns were erased by the language of universal human rights. In contrast, women in post-communism are seeking to regain their gendered identity, their individual agency, their personal subjectivity, becoming "flesh incarnate." This transformation, I argue, intimates an intriguing permutation 
of the singular notion of subjectivity, into a complex matrix of women-assubjects, a plural incarnation "living among them."

Despite my figurative metaphor, there is no facile formulation of either/or, communism or post communism, universalism or materialism, word or flesh; rather, one must seek to understand how the legacies of communism are enmeshed in the complex web that defines the Czech Republic today, a web networked into the convoluted threads of today's global economy. Thus, in my paper I will in no way attempt to legitimate my reductionist motto; yet, at the same time, I do not merely want to offer a simplified review of Czech women's fiction or do close readings of certain exemplary Czech woman writers on the one hand, during communism and during post-communism, on the other. Rather, my paper seeks to interpolate all three of these approaches to grant the reader a three-dimensional perspective on Czech women's writing, which is why I chose this particular parable as a panoramic overview of the changes in the landscape of Czech women's literature, pointing to both contemporary Czech politics and Czech feminism; for indeed, from afar, such topographical features (such as voice/ language, universalism/ individualism) do appear to characterize it. However, in my review of Czech women's literature, I will not cease to problematize this horizontal view of Czech literature, pointing to the many landmarks that puncture a stereotypical gaze. Finally, I will zoom in on the work of two women writers, Eva Kantůrková and Iva Pekárková, whom I consider to be representational of the concerns of communism and post-communism respectively, in order to not specify them as types but also differentiate them in their individuality. In so doing, I wish to probe what it means to be marked as "a Czech women writer" today - incarceration in a gendered, fictional, body-figure? Or incarnation into community, the body Czech women writers incarnate?

"IN THE BEGINNING WAS THE WORD..."

My chosen parable "in the beginning was the Word" reveals a literary turn, a turn to language and discourse - in many ways different from contemporary feminist analysis of Czech women. Note that I did not choose, for example, an allusion to the relations between Adam or Eve, or the cultural difference between the Samaritan and Jewish women. Indeed, the two salient features of contemporary gender analysis of the post-communist Czech Republic are its sociological emphasis, in a man/woman differential, and its criticism of Western feminism, in an East /West distinction. Czech feminists such as Věšinová, Kalivodová and Čermáková ${ }^{1}$ as well as others outside the Czech Republic, such as Rosemary Crompton or Alena Heitlinger, ${ }^{2}$ have written numerous articles about the status 
of women in Czechoslovakia or the Czech Republic, on issues such as gainful equality, political representation, abortion and women's rights. Others are identified by their work which focuses on East-West differentials, such as Jiřina Šiklová who has reached English-speaking readers with such articles as "Are Women in the Czech Republic More Conservative?," "McDonalds, Terminators, Coca-Cola Ads and Feminism" and "Feminism and the Roots of Apathy in the Czech Republic," where she points to, as she titles it, "imports from the West." My parable points to a different viewpoint on the same feminist questions - an appropriately literary one, given my training as a theorist of comparative literature. As such it privileges the role of language, the literary word, in the postcommunist economy and takes a narrative approach, which operates diachronically. In no way do I want to discredit these reputed feminists; on the contrary I want to engage them in dialogue, to show how a literary outlook might comparatively complement many of the issues already raised in criticism. These theorists have been instrumental in showing the specificities of Czech women and, indeed, those of many post-communist nations - especially as concerns the structure of "equality" or "pseudo-emancipation," which led to the "new woman's fate" (Navarová). Under communism women were expected to work, which in many ways differs radically from Western women, and has resulted in a distinctive attitude in post-communism: women reject the assumptions and presumptions of Western feminism as such and ideology in general. I would like to show how this dismissal reflects a deep-seated disillusionment with the language of discourse itself, which, in its essence, presumes a collective universalist whole.

\section{“...A A D THE WORD WAS GOD”}

In the beginning then, in communist Czechoslovakia, as well as in most other communist Eastern European states, the Word was God. This omnipotent Word was, of course, first and foremost that of the Law, the oppressive totalitarian communist regime, founded on the writings of Marx and Lenin, which controlled all government, legal and social institutions. However, in this authoritarian system, the literary word also attained quasi-sacred if not salvational dimensions as it embodied a deliberate resistance to the communist state. Through the written word, writers were able to express themselves independently of the regime, and often, as dissidents, oppose this regime. Such dissidents essentially fought for human rights, a struggle of global dimensions, written in a common, internationally understood language. Even though they were eliciting intense accounts of concrete individual experiences, such writers nonetheless pointed to 
the universal essence of life. From a Western point of view, it would thus appear that Czech writers, oppressed by the communists, in their struggle for universal human rights, effectively shared a similar Western world-view.

Such a point of view, however, is deceptive. Numerous theorists, from Freud to Foucault, have argued that in Western society sex is the formative factor in defining normativity and that normativity is the determining process of institutionalizing power. Other theorists, notably post-colonialist, have shown that power operates on social "differentials," like that of sex, of normal/deviant, marginal/central, or East/West in this case. In the communist system, unlike in Western society, such valorization of the written word, established the Word discourse itself - as the axiomatic paradigm of power. As Foucault might put it, it was not any particular "discursive formation" but the formation of discourse itself that established and maintained itself as power. Now in post-communism this accounts for disenchantment with the social discourse itself, any "ideological dressing" or any "isms." Feminism in particular, "mistaken for a condensed ideological symbol," has acquired "demonic connotations" as Čermáková explains:

Gender discourse is unilaterally burdened with misunderstood concepts of 'feminism' and 'feminist sociology' to the point that the notions have nearly demonic connotations. Comparable demonization can only be found in the darkest period of the 1950 s when notions like 'capitalism' and 'western sociology' were refused with similar vengeance. Whenever feminism and feminist sociology, which in reality exist as part of the pluralist stream of thinking and theory, are mistaken for a condensed ideological symbol, no discourse is possible. (1-2)

What makes matters more interesting is, as Vodraška points out, that "[s]ymptomatically, the critical attack on feminism has been launched by women, not by men" (2). Of course, such attitudes allow men to act out, albeit humorously, any anti-feminism they may have (such as Škvorecky who wrote a rather scathing article by North American PC standards which easily "passed" in the $\mathrm{CR}^{5}$ ) or enable men to speak in the name of women, such as Havel, who, unproblematically writes as a representative of Czech women that in the Czech Republic feminism is but "dada."

Such reactions stem from the undifferentiated view both men and women have of any gendered subjectivity, espousing rather common national or human rights and so always viewing themselves in a collective whole. Such a tradition stems as far back as the emergence of Czechoslovakia as a nation. Thomas G. Masaryk, which many consider the father of the Czech nation, though he included women in all national issues, ${ }^{7}$ inadvertently advocated human and civic issues above national and particular interests, including women's, bluntly stating that "there are no women's issues, there are only human issues." ${ }^{8}$ Under communism, 
of course, the official discourse enforced a negative form of equalization, where, as Havelková describes, "differences were removed by being suspended and ignored, prevented from becoming public, or bought off' (65). However, this same form of equalization was re-appropriated as positive, liberating rhetoric by the heteronormative counter-power to that of the state - intellectual dissident writers, who sought to promote universal human rights in which gender was subsumed under general, existential, humanist problems. In all of these discourses, gender identity was naturalized and personal subjectivity neutralized, which had to have serious consequences on the recognition of "women's issues":

The lack of interest in women's problems originates in the syndrome of putting general human problems above particular issues of sex-related identity, an attitude strengthened by the pre-revolutionary political dissent, which focused on issues of political freedom. An assumption that sexual identity is natural, as well as the conviction that women's emancipation has been accomplished and that no one has really benefited from it, all discourage attention to women's issues. (Havelková 65)

Though Havelková is referring here in particular to the official discourses of precommunism and communism, I would contend this is symptomatic of countercommunist and post-communist language as well.

Under these conditions, the notions of subjectivity are foreign to the majority of Czech people, and even more so is the feminist model of women-as-subject, a notion propagated from de Beauvoir to Butler. ${ }^{9}$ As outlined above, given Czech history, questions of women-as-subject were dismissed in the name of universal solidarity: in the nationalist period, men and women united for the cause of an independent Czechoslovakia; and in communism, the totalitarian regime propagated communal relations and at the same time urged men and women to ally against the state. Moreover, it should be mentioned that unlike Western women, Czech women never had to fight for some of rights their Western counterparts did, such as suffrage or maternity leave, for example. The former was granted to them automatically when Czechoslovakia became a state, and the latter came along with many socialist reforms. So in one respect, Czech women, well acquainted with the concept of sameness, both in the negative sense of equalization but also in terms of solidarity, were simply unaware of the conception of "difference": "In the priority of modern Czech desires, be they nationalist or later socialist, women has not only to disregard her own gender, but she had to dissolve herself into the pantheistic porridge of 'human' manliness" (Vodraška 6). And such undifferentiated thinking continues to persist in postcommunism:

Even though post-communist general thinking has transformed the political structure, it has nonetheless adapted the traditional model, based on modernist prejudices, of 
'brotherly' totalitarian sameness. 'Mankind,' in the post communist era, is as unquestioning of this model and is unaware that the world has entered the abyss implied by difference... (Vodraška 6)

I would argue that becoming a dissident writer, an intellectual, intimated a further renunciation of any embodied subjectivity. Writers under communism seemingly had a choice: either to conform to communist propaganda and relinquish all attempts at original, independent thought, thus submitting to emasculation and enforced silence, or to defy the totalitarian authorities and thus become a nonperson and risk physical annihilation. In both cases, the writers' engagement with the written word signified a renunciation of their physical selves, their gendered bodies. On one hand, by silence and acquiescence to the communist regime, conformist writers accepted the doctrine that all men and women are equal - the community of the working proletariat - and thus are not sexed or divided. On the other hand, as dissidents they subsumed their sexuality in favor of promoting universal human values. How to interpolate a third choice, that of gendered writing, women's writing, into such a system?

The question of women's writing becomes particularly problematic in such an economy. Like many writers, women writers struggle with the difficulty of advocating universal human rights, while at the same time, describing their everyday locus in society as women, be it wife, mother or worker. Most importantly, women face the difficulty of inscribing their bodies, sexed and gendered, into a system, which has supplanted the economy of the flesh and desire to that of word and idea.

In many respects, the presence of women was erased in the writing economy itself; many chose not to write for a variety of reasons. For example, only $20 \%$ of the signatories of Charta 77, the Czech writers' anti-communist manifesto, were women. As some theorists such as Hrabik-Samal have pointed out, women represented the "whited-out" "blank" spots of the dissident writers economy (81), not because they did not directly participate in the production of the written word as writers, but because, on the contrary, they represented the physical, corporal reality by which the written word was brought into being. As HrabikSamal's work explains, many women (such as Anna Šabatová, Olga Šulcová, Zdena Škvorecká, Zdena Brodská, and Ruth Tosková) became the editors and publishers of various samizdat magazines and émigré publications. Others (such as Zdena Erteltova-Phillips, Bronislava Müllerová, Ludmila Piatková, and Klára Pokorná) spent countless hours typing and typesetting such unofficial dissident writing. Still others (such as Ruth Klímová and Eva Šimecková) translated the works of these dissident authors. We must also mention the immeasurable efforts of the countless women who supported their husbands or friends, often 
imprisoned or persecuted (such as Olga Havlová, Jolana Kusá, and Kamila Bendová), who opened their homes as meeting places or shelters for various dissidents, who hosted conferences and seminars, who communicated information, and finally, who distributed dissident publications. However, there were also women writers, many of them engaged both in the process and creation of literary works, and a number of them were imprisoned for these contraband activities. In the communist period, then, the written word overshadowed women's presence, although their materiality itself was vital to its production.

Women's literature was also written under socialism. Such literature sought to explore women's themes, especially those of women's roles in society, at work and at home, essentially probing the whole notion of "woman's identity." However, given the dominant discourse, such women's voices were erased:

It is only in sociology and women's literature that one begins to find the female contours behind the anonymous, universal workforce, a discussion of contemporary women in nontraditional situations, and the necessity of new criteria for assigning value to socially useful work by women. Several female authors, including V. Hanzová, V. Švenková, E. Farkagová, G. Rothmayerová, L. Hajková, and J. Bodnařová have in short stories, novellas, and poems made the daily struggle against time of their female protagonists the major theme. The lack of time for herself, for the children, for the husband she loves; the lack of deep, quiet, or shared experiences; and the feeling of estrangement are often described as the characteristic themes of our female literature. Literature written by women has also dealt with the theme of women's identity, contributing to 'revealing' that identity and helping thematize the world of women anew. It has been oriented toward private life, toward the emotional sphere, toward the plane of interpersonal relationships in the circle of the family, and has often stayed far away from the 'great and heroic themes of the building of socialism.' These authors have endeavored to define a social role for women that corresponds to their bio-psychological and socio-cultural constitution... Such literature has often been characterized as 'escapist' literature by a literary critical apparatus dominated by men. (Kicková and Farašková 87 )

Kicková and Farašková's succinct summary of Czech women's writing in socialism points to perhaps the greatest difficulty facing women during the communist period: translating their gendered subjectivity into the language of humanist universalism. I would now like to analyze the work of the most engaged woman writer of the time - Eva Kanturková, whose work in many ways epitomizes this ideological quandary, a double-bind nicely captured in this portrait of her by Alena Heitlinger:

One of the three rotating spokespersons of the main dissident organization, Charter 77, was always a woman. The documents of Charter 77 reveal that they did not devote much attention to women's issues, but to the extent that they did, reaffirmed the principles of women's equality and women's right to work. However, the dissident writer Eva Kantůrková urged women to reject the Marxian ideal of emancipation, which in her view communism transformed into a new form of women's slavery: obligatory employment. 
Instead of seeking emancipation through paid work, Kantůrková urged women to rediscover their 'authentic traditional feminine qualities of compassion, love, and tolerance.' Like most other dissidents who took some interest in women's issues, Kantůrková found universalist concepts of human rights and human liberty more relevant to women's circumstances than the ideas of Western feminism. (Heitlinger 1993, 105)

As Heitlinger points out, Kantưrková certainly understands the problematic women engage in - forced "equal" emancipation, meaning cheap labor - yet her solution is perplexing indeed. She turns to the language of universalism to intimate some essential type of "authentic feminine," which she defines however in humanist terms. For are not "compassion, love and tolerance" to be espoused by both men and women? How to speak as a woman when one is only read as human? Such was the difficulty of women writing under communism - voicing themselves not from a minoritized position guilty of discrimination but rather, one of equality already presumed.

\section{N C A R C E R A T I O N}

Eva Kantůrková's most successful book, perhaps one of the most famous examples of "woman's writing" under communism, My Companions In The Bleak House (1987), divulges this difficulty, albeit implicitly. I posit it, however, as a particularly effective rhetorical strategy, and perhaps the only performative one possible in this economy. In many ways, My Companions deviates from other women's novels of the time. Firstly, it is not a novel but an autobiography, and not a traditional one in that it does not seek to construct authorial subjectivity but rather dialogically is the object of a multiplicity of subject authors. More importantly, unlike other women's fiction, it does not concern itself with the domestic sphere or work, or even the question of equality. It is literally incarcerated; the book details Kanturková's 1981 stay in Ruzyně prison, where she was detained for a year with women from different walks of life. Yet despite the erasure of the question of "emancipation" and "equality," it focuses almost exclusively on the meaning of "woman" and the pluralist community of "women." This feminist message is conveyed, I argue, precisely because it so successfully translates these feminist concerns into the humanist grammar of the times.

In the preface, Havel summarizes the book "an account of women in marginalized situations - that is, an account which is universally human" ( $C B \mathrm{x})$. Rather than admitting to any gendered specificity, Havel stresses its portrayal of the human condition. He claims that though it occurs in a prison, it magnifies in microcosm the oppression and limitations inherent to the communist state, which Havel aptly relates to the existential life situation: 
The plotlessness and non-happenings of life in a prison-cell cast a new and very peculiar light on the stories and events that have happened to us before, on the outside. This is a moment of truth - the truth of my fellow prisoners, my truth and the truth of the world in which it has been given us to live. ( $C B$ xi)

In Havel's opinion, all the themes in the novel are universal, including time, which, rather than being political, is appositely linked to the "outside," and reflects the peculiar "in betweenness" of time in general:

Another theme of this book is prison-time, which is that strange 'time/non-time' which offers sharp insights into a more far-reaching enigma, one which touches all of us, that is, the enigma of human time in general. ( $\mathrm{CB}$ xi)

Given that Kantůrkovás novel may be read for the overreaching universalist themes, which indeed mark communist writing of the time, her novel also presents us with a situated perspective that makes a reader such as Havel uneasy:

There are situations in this book about which I have a very special feeling. They interest me, they surprise, touch irritate and intrigue me. Sometimes they make me bristle inside, but at the same time, I'm fascinated. I can only explain this particular aspect of my own feelings about Eva Kantůrková's book by the very specific and undisguised femininity of the author's personality and the way she sees the world. ( $\mathrm{CB}$ xii)

For Havel, not only does Kantůrková's work reflect a women's point of view but also that of a woman of the word, an intellectual woman. Havel, comparing her to companions, signals her status as a writer; commenting on the difference between her and the other inmates, he explains "they're simply different - unhappy in different ways, good and bad in different ways" ( $C B$ xii). Yet at the same time, Havel lauds her egalitarian treatment of these women, such democratic egalitarianism being the trademark of human rights writings of that era. Ironically, Havel remarks that Kantůrková "sees each one of [these women] separately, as concrete autonomous individuals" ( $C B$ xii), yet he himself reduces her to the generic epitome representing the universal human condition vying for freedom.

Despite its clearly universalist tendencies, Kantůrková's book focuses on women. For example, the account begins and ends on March 8th, International Women's Day. The warders attempt to take this day away from the women by raiding their cells, tauntingly claiming "You're criminals and Women's Day's got nothing to do with you" ( $C B$ 14). In this way, they wish to reduce the women to sub-humans, to whom the categories of men and women no longer apply. Nonetheless, the women resist this dehumanization, precisely by celebrating not their humanity but their womanhood. The tenor of the celebration is interesting because it is conducted without words or, more precisely, without Czech words that the other women in the cell understand. It is an obstinate Hungarian Gypsy, 
Fanny, who organizes the celebration; she rearranges the furniture and teaches everyone in the cell to dance Hungarian czardas, while she sings Gypsy folk-tunes.

This celebration, one of the most jovial scenes in the novel, points directly to the question of language elicited in the novel. In the novel, language functions as a means of survival, as a form of pleasure and release for the "prisoners [who] must amuse themselves as best they can. And they need contact with other human beings." Reading is not a possibility, for "the sort of reading available aroused derision rather than interest." It is primarily through narration, writing and speaking, that these women recreate another reality: "Sign language, the Morse code clapped or tapped on the heating pipes, the toilet phone, messages on horseback, banging on the floor - these were all substitutes for conversation." In these lapidary conversations, women do not attempt to convey information but rather communicate with lovers, spread gossip, and create new personae for themselves: "Intrigue was the breath of life in the women's cells: the prison would seem to be heaving with repressed passion. Lies, excuses, courtship, persuasion, assurance and promises fed both love and jealousy, the only two things that could keep boredom at bay" ( $\mathrm{CB} 32)$. Partaking in the spoken word was associated with shame: in order to communicate most directly, women had to squat on hands and knees and yell through the toilet pipe: "the very idea symbolized the hell of prison" ( $\left.C B{ }_{27}\right)$. Notwithstanding, women challenged the silence imposed on them and subverted the dominant language of the system, a language which defined them as criminals and subalterns. For example, one of Kantưrkovás companions, Helen, continues to write to the authorities, even to the President of the Republic, despite the fact she could not spell simple words. Though imprisoned multiple times, this criminal's harshest swear word was the word "elephants."

Language directed outside the cell was thus a deceiving diversion, which resisted the oppressive order by both reappropriating and subverting it. This inversion is perhaps most evident in the "messages on horseback," notes that the women passed through the barred windows, which in content and form resembled traditional letters: they had an address a recipient and sender and in content contained formulaic expressions of love, often plagiarized poetry. Yet these idealized letters had little to do with the women's everyday reality; they were mere resistance to silence and boredom. For example, Maddy, a Gypsy foundling, spends the whole day writing and drawing such transcendental letters: "every piece of toilet paper that we got into the cell was covered by her writing, and she was always begging the trusties for the packets of sanitary napkins that came in" ( $C B$ 19). Yet though she would write about abstract values in her letters, 
Maddy's character was much more prosaic, her main preoccupation being how to get hold of cigarettes, paper and money to get a few necessities.

Inside the cell, among the women prisoners, language functioned on another level to create a community of women, women bonded together by a common sadness: "what you live with is sadness; and sadness becomes a bond, a bond as strong as that of the humiliations you have suffered together" ( $C B$ 17). "I must tell you Eva dear" ( $\left.\mathrm{C} \mathrm{B}_{23} 3\right)$ - this is perhaps the refrain of the novel, which consists mainly of the stories of Kantůrkovás fellow prisoners in their common cell, stories of survival. Through these stories, Kantůrková realizes that literature is not only the written word: many women who could not write would recount lovely fables, many who could not read would sing their lives. Fanny, the Hungarian Gypsy who spoke no Czech, expresses herself through her body language.

Thus, in the prison, through dialogue, Kantůrková is inextricably linked with women of all walks of life by a common bond - sadness and helplessness - and by a common struggle - waiting and questioning. In her final passage, she, who has mostly been a listener in these conversations, expresses her solidarity with these women; in a touching passage, she simply asks her lost friends question upon question. And leaves us waiting for their reply.

Indeed, in her poignant depiction of imprisonment characterized by waiting and questioning, Kantůrková deftly allegorizes the incarcerating atmosphere of communist Czechoslovakia. In her focus on language, she privileges it as a means of liberation from such incarceration. Yet, she refuses the abstract language of stereotype and ideology, such as that of the "messages on horseback," pointing out that such language served only to amuse or to deceive and conveyed no real messages. The code that does translate meaning for these women is that found among them, in the intimacy of their cell, in the language of fable, song and dance whose syntax is that of women's memory and women's body.

Not only does Kanturrková deconstruct the axiomatic paradigm of the communist and anti communist discourse - the notion of discourse itself - in order to posit a feminine language, she does so in a particularly revealing manner, an approach certainly worth noting with respect to a feminist subject position. Nowhere in this autobiography does Kantůrkova assume the locus of the authorial or authoritative subject; rather her work is an intricate heterotopia of different women's voices, positions and stories. Unlike her Western feminist counterparts who all too often adopt the traditional hero narrative, in which a woman protagonist "empowers" herself and "asserts her subjectivity, agency and voice" by simply replacing the traditional male hero with a female heroine in the patriarchal narrative model of acquisition of power and evolutionary progress, Kantůrková avoids any such role reversal or any such facile formulae. Instead, she 
offers us a different model, in which she does not create an individual woman as subject but rather recreates a complex matrix of women-as-subjects. Such a feminist perspective is worth noting, especially given contemporary Western criticism of East European women's subjectivity in post-communism, which some claim is its "suppressed subjectivity"(Havelková 68). At the same time, however, these Western feminists, in addressing post-modernism, are only beginning to question the positive concept of the subject, such as when Rosi Bardotti states: "The problematic of women as subjects is just beginning to be explored" or "Women cannot afford to argue for dispersion and fragmentation..." (Braidotti 121). Perhaps Kantůrková's work, and indeed that of many women writers under socialism, must be re-evaluated along these lines, not in the fact that they lack a Western concept of subjectivity - the individualist "woman as subject" - but rather that they operate within a framework where women in their most plural sense already are subjects.

Kantůrková also broaches certain issues crucial to later post-communist concerns, specifically: the materiality of the body and capital. Kanturková's emphasis on the word is founded on the weakness of her own flesh. She is ill throughout her stay in Ruzyně, confined to bed. For her, the abyss of the exercise room "is the blackest of Black Holes, one of the assholes of the world" (CB 6). According to Kantůrková, the pernicious and ultimate destruction is achieved quite simply through lack of oxygen. In harrowing passages, she describes the allencompassing, overwhelming prison smell: the unwashed bodies, the stench of sicknesses, the toilet and the bad food, the fetid, moldering smell of air breathed over and over again: "Then you are left with half your strength - and that is what your interrogating officer is out to destroy." ( $\left.C B{ }_{5}\right)$. This prison smell is compounded by stale cigarette smoke, which brings us to the material capitalist economy thriving in the prison. In a number of passages, Kanturková emphasizes the ultimate value placed on this merchandise, describing the efforts to which women go to acquire paper and cigarettes, the bitter fighting among the women derived from both their presence and absence.

"AND THE WORD BECAME FLESH..."

Kantůrková's work advances many of the key concerns in post-communism; thus one can hardly argue for a radical revolution around the marking "post" of 1989. If one looks at the level of hegemonic regime, however, just as communism privileged the imaginary paradigm of the Word, post-communism is marked by a return to the materiality of the flesh. Post-communist Czech society is marked by a distantiation from great ideas and universal values, towards the self, material 
reality and local knowledge. In the transition to a Western-style democracy and market economy, the literary merits of many intellectuals lost their aura as the ordinary Czech people were now required to adapt themselves to their new conditions of freedom of choice, expression, and purchase. The lofty humanist ideals of the dissident, anti-communist writer seem incongruous with the newly acquired values of individualism and social mobility. With hindsight, it now appears that the task of the dissident, anti-communist writers was simple: it is always easier to fight against oppression than to unite to support any constructive program. And indeed the problematics of "creating a civil society," as Havel announced in the opening speech of the new republic, are the main difficulties that the Czech Republic is facing right now.

Above all, much as in Kantůrková's text, there is generalized disillusionment with discourse itself - skepticism with any "isms" as Czechs like to term it, and feminism is also regrettably included. As Šiklová points out, many Czech women are "allergic" to or even made "nauseous" by Western-style feminism because of its ideological assumptions, grounded and repudiated by the oppressive material conditions of socialism:

The ideological character of feminist trends makes us feel some nausea, which in the past we used to experience with references to 'class struggle'... We have unfortunately become certain that someone who has previously been exploited or oppressed is not necessarily the best leader of society. Socialism was a failure... We are, beyond doubt, captives of our past. I am afraid, however, that at the same time West European and American feminist intellectuals are captives of their own ideology... our feminist movement is going to develop not on the basis of taking up some great ideologies, but rather on the basis of solving concrete non-political tasks. (Šiklová, 78-79)

Not only do these ideological "isms" deviate into the abstract instead of "solving concrete political tasks," they are, as posited in my introduction, alien to the majority of women, who are not only disenchanted with "class struggles" but also mystified with the Western concept of subjectivity.

It is fundamental to understand that in the deforming economic and political structures of the communist regime personal subjectivity was repressed and could not even be conceptualized as such. Given the lack of personal freedom and material advancement, many people, and women in particular, simply did not learn to say "I need" "I want" "I desire" - the personal "I" so fundamental to the conceptualization of the enlightened Western autonomous individual simply had no opportunity to emerge. No one emphasizes this point more clearly than Šmejkalová Strickland:

For at least the last 20 years, very few people here had a chance to say 'yes' to their lives or to themselves. Very few found their way out of the webs of dissatisfactions, feelings of 
guilt and fault, feelings of having missed the boat. Institutional, political, and intellectual constraints - often more anticipated than experienced - did not allow one to live or to theorize the limitless, strong 'I.' (280)

In order to be able to deconstruct the patriarchy or traditional gender roles, which enforce the dominance of male subjectivity, one must first have had to have learned to think in gendered terms. And this was not the case in the Czechoslovakia, where the personal subject, gendered or not, was not even constructed:

To deconstruct the subject, one must first have gained the right to speak as one; to subvert the existing order of signs, one must learn to use them... Neither She not He had spoken as one here, neither She nor He has constituted Her/His voice. Because in many aspects the very construction of the ideal Subject was missed, its deconstruction could not have been part of any Imaginable discursive and political project, and must seem strange to anyone here when presented as something to strive for. (Šmejkalová Strickland 280)

Šmejkalová Strickland refers to the broken psychoanalytical tradition in Czechoslovakia as a primary reason for the repressed subjectivity in former Czechoslovakia, and in so doing states the crucial element that I wish to highlight in this paper: the resulting absence of a tradition of gendered subjectivity and, in particular, a gendered subjectivity embodied in social discourse:

If debates among both Freudians and anti-Freudians helped Western feminists to ask how deeply patriarchal identities go, how female and male identity can be represented in language and cultural stereotypes, this stop is missing from our recent cultural and intellectual history. Moreover, there does not seem to be any space within the public consciousness for the articulation of the notion of gender or for confronting the problems of identity, self-knowledge and self-expression, which such a notion would entail... Both women and men somehow lack the habits and language to articulate their hidden feelings and the needs and demands connected to their 'I.'...

Not only the question of 'How do I understand my - gendered - soul?' but also 'How do I understand my - gendered - body?' was commonly asked. (278)

The search for a gendered body and an understanding of gendered subjectivity, as I will attempt to show, is only now beginning to emerge in post-communist women's fiction.

It would appear that the local positioning of women as gendered subjects would privilege them in the post ' 89 system, now highly concerned with the self, the body and material realities. Indeed, women's fiction has considerably increased in the last decade; however, it remains an unappreciated genre as such. Why? The answer to this perplexing question lies in the composition of the novels themselves and also in the constitution of women in Czech society.

Wary of all-encompassing, universal themes, post-communist women's fiction has disaggregated into subsidiary themes, with each individual author 
concentrating fixedly on specific aspects of women's life experience. Much like most women writers under communism, Teresa Boučková, for example, directs undivided focus on women's local materiality in novels such as Indiánský běh (1991), Křepelice (1993), Když milujete muže (1995), and Krákorám (1998); she relates the mundane, everyday life of women as mothers, lovers, and wives. In her terse, pithy style, Boučková poignantly illustrates the banal, wearisome, often overwhelming lives of ordinary women, characterized by work and repetition, and often unfulfilled by love or excitement. Her novels offer no easy solutions or escape from such drudgery, yet in so doing, her novels seemingly lack intrigue, interest, and, above all, hope.

By contrast, Iva Herciková, in her sensationalist pulp-fiction novels Hester: aneb O čem ženy sní (1995), Rady mladému muži (1996) and Vášeñ (1998) rivets the reader's attention on the intense, devouring passions, desires and loves of women. Such pulp fiction is not to be dismissed; it represents the contemporary "best-sellers" in the Czech Republic, largely for the most part translations of American pulp fiction by authors such as Jackie Collins. Moreover, it is crucial to note that such feminist authors as Iva Pekárková and Eva Hauserová make their living translating these novels, the income from their own feminist novels being insufficient to support them. This ironic situation in many ways perpetrates the hegemonic economy not unlike during communism when dissident women writers sacrificed their own work in order to type, translate and circulate the work of others. This is not to say that these novels are bereft of allusions to women's economic and social realities; however, the resolution of these issues is utopian and problematic. In Vášeñ (Passion) for example, Herciková recounts the erotic encounters of Pírko, an expatriate Czech woman in the US who leaves husband and child for a Czech lover in New York, who soon abandons her there. Without a viable job, family or friends, Pirko succumbs to despair, until, deus ex machina, she is handicapped in a tragic accident, whereupon she is rescued by her husband. Without a doubt, the novel leaves the reader troubled; women are portrayed as alone and without agency, not safe unless in the hands of their husbands, seemingly incarcerated in their bodies and their gendered realities.

Daniela Hodrová's work offers yet another model of women's writing - a return to the Word in a much more intellectual vein. In her novels, Kukly, Theta, and Perunưv den, Hodrová reappropriates traditional overarching narratives, which she terms as "myths of initiation" - the myth of Orpheus, the myth Theseus, the myth of Christ, and symbolically reinscribes them in the lives of contemporary women in Prague. In Peruni̊v den, for example, Hodrová takes up the Christ myth in a highly apocalyptic tone, designating all of her female characters as gospel evangelists, who narrate the experience of their daily lives. 
Though she intricately weaves together a dazzling array of symbols from the Bible and antiquity, as well as Prague realia from the 1990s, her text remains opaque and seemingly void of meaning - her apostles bear no good news. On the contrary, Janů, the apostle of the Word, ${ }^{10}$ dies, or rather 'is reincarnated,' her last words the prayer: "ile ele nusom veset ilson elson." It is not a prayer but the conjugation of the verb to be in French. She conjugates the verb in the past tense, the future - nous serons, vous serez, ils seront, elles seront- and then is heard no more.

This contemporary women's fiction illustrates the difficulty of conjugating the verb "to be" in the present tense and, even more importantly, the obscurity of "reincarnation" in the future tense. For me, however, this women's fiction reveals a more fundamental problem, that of creating a community of women. Janůs apocalyptic last words - "nous serons... elles seront" - are not meaningless here. In her text, Hodrová presents us with a group of women, who, though they have known each other since childhood, cannot express a common goal; they can only reminisce about their idyllic past. Similarly, in Herciková and Boučková, the women, be they wives, mothers or lovers, are fundamentally alone.

Eda Kriseová, a writer before and after the 1989 Revolution perhaps best identifies this need for community in her latest novel: Kočiči životy: román (1997) (Cats' Lives: A Novel). Before 1989, her work, Křizová cesta kočárového kočiho (1979), Klícni kůstka netopýra a jiné povidky (1982) and Arboretum (1987) consisted mostly of short stories, told in a fairy-tale style and dealing with such overarching themes as love, friendship, jealousy and betrayal. Kočiči životy, though characterized by many of her former attributes, such as lyrical love passages or stylized character portraits, nonetheless attempts to describe a new world full of unfathomable potential, will and movement, as her epigraph from Hesse suggests:

What is to come we cannot imagine. The soul of Europe is an animal, who, for too long, has lain chained. When it will be free, its first movements will not necessarily be pleasant... Then it will be our day, then we will be needed, not as leaders and new lawmakers - merely as those who are willing, to are able to go and stand there, where destiny calls them. $(K Z 6)^{11}$

In order to reach this potential, Kriseová delves into the past, when Czechs were forced to emigrate to Volýň, Ukraine, and traces the genealogy of a Czech family who settled there. In order to elicit intrigue and passion, she reaches for episodes when the existence of the Czech community was menaced, true to her second epigraph from Vladimír Holan: "Being is multiplied when threatened" ( $K Z 6$ ), which could equally apply to the situation of Czechs under communism. In her depictions of the Czechs in Volýn̆, from the devastation of the war to the disaster at Chernobyl, and of the family struggling in communist Czechoslovakia, Kriseová portrays a close-knit community, which celebrates the heroism of its members 
and endures its betrayals. However, a noteworthy shift occurs as Kriseová concludes the novel with the account of the last member of this family, Liza, who lives in the free Czech Republic. Liza, who devoted her life to the service of others as a doctor, remaining chaste all her life, is at the end visited by the love of her youth, who in the interim had emigrated to the US. She cannot forgive her former flame for his abandonment and scorns his success in that materialist world. He dedicates his last book to her, titled My First Love. Líza laughs as receives it and notices the cover, that of a carefree young woman standing before the Jewish ghetto burning in the distance; she cannot reconcile this image with that of her current self, which she holds to be true, that of a weathered old hag (324). In the same way, Líza is disturbed by a photograph of herself in a famous café, representing the three generations that have defined who she is; she has difficulty recognizing the woman she used to be $\left(K Z_{340}\right)$. She realizes she has become a legendary image, a literary figure $\left(K Z Z_{325}\right)$ for those who want easy answers $(K Z$ 327). Yet there are no easy answers; with her family and friends dead or far-away and the new government policies transitory and uncertain, Líza continues to question why she is so resigned to go on, to suffer and to remember this past (KZ 335). The book closes on Líza alone in her solitary apartment with her only company her cats.

\section{A N D LIVED AMONG US...}

In many ways, Czech women are faced with the same problem as Czech society itself - that of creating a viable community. In the communist period, women seemed both liberated and incarcerated by the Word made God. And now in the post-communist period, their incarnation seems possible. However, incarnation means consolidation, not only of the individual body but also of the whole, in community. Jiřina Šiklová describes the difficulty of Czech women to embrace a definable women's movement or political entity or community as defined by Western feminism:

We have not demonstrated; we do not revolt as women. In this country, the political struggle for women's rights has not been included in our program. Czech women were obligatorily organized for too long; hence they connect liberty with the liberty to not be organized in any way. (Šiklová, 79)

How to assume both freedom and community? In order to explore this question, I now turn to the work of Iva Pekárková. The choice of Pekárková as my final and exemplary model of Czech women's writing may appear controversial to some, given that she is an "emigrant" writer. Pekárková lived in New York for ten years, from 1984-1994, and although this exile was relatively short-lived, she is now and 
forevermore to be considered a "half-foreigner," especially by academic critics, who like to categorize her as a unique exception, as, for example, a feminist émigré "post-exile" subjectivity (Heitlinger 1999). "Post-exile" places her in a "amorphous positionality" and "intellectual modality - always contingent and subject to revision" "which must be disentangled from a one-dimensional and one-directional conception of history" but rather "which emphasizes the inextricable presence of the past, in this case the continuities of the conventions of exilic subjectivity" (Manicomb 41). In no way do I want to challenge her emigrant position, but I would argue that in its "amorphous positionality" and "intellectual modality" or "inextricable presence of the past" Pekárkovás work also best captures and characterizes the transition from communism to postcommunism as a fluid, hybrid one, in which Western encounters and former communist experiences are constantly being re-evaluated and questioned. Though set in radically different contexts - from communist Czechoslovakia (Pera and perutè), to an intermediary refugee camp in Austria (Kulatý svět), to independence in New York (Dej mně ty prachy, Gang zjizvených) - her novels are all characterized by similar themes, and thus aptly depict this transition as a transformative shift from a totalitarian system to a market economy rather than as a revolutionary rupture. Moreover, her novels only intimate what is to come for the Czech Republic - migratory movement towards a global, multicultural economy - in which again, the referent to the individual subject's voice and agency may be lost in deference to a more worldly universal one.

\section{N C A R N A T I O N}

I wish to focus precisely on this moment of modulation, best characterized in Pekárková's second novel, Kulatý Svět (The World Is Round). Set in a refugee camp, it allegorically symbolizes the in-between, liminal locus of transformation between her two worlds, or rather the hybridization or all-worldness of her experience implied in the all-encompassing circulatory reference of the novel's title, The World Is Round. The novel follows the account of Jitka, who, after years of dreaming of free countries beyond Czechoslovakia, crawls under a barbed wire fence to Italy only to find herself incarcerated in another limbo waiting for a visa in an Austrian refugee camp incongruously set among picturesque grape fields. The refugee camp is a space of both liberation and incarceration. Refugees must live in a filthy, crowded, dysfunctional camp, waiting to be accepted by a host country, while at the same time being enclosed in a flourishing environment, a prosperous society, whose benefits they can enjoy, if they dare, as illegal labor. 
The refugee camp reflects the process the individual and a society itself must endure as it proceeds from a repressive authoritarian regime to autonomy.

The camp, "international small town" (WR $\left.8_{3}\right)$ is described as "a confusion of tongues" (WR 9o), a cosmopolitan Babel of sorts, with refugees from all over the world who only seem to arrive and never leave. As in Kantůrkovás book, camp life is concerned with the quotidian - washing, cleaning and others' snoring - and likewise fizzles "with small loves and passions and hatred and an incredible amount of time to be killed" (WR 83 ). As in Kantůrková, conversation also functions as a fundamental feature characterizing camp life: this "killer time" is spent learning languages, especially those of the countries to which they wish to emigrate.

Language is crucially important in this setting; in order to leave it, the refugees must master the art of making up a good enough story to be granted asylum in a foreign country, preferably Australia, Canada or the US. Those who have suffered must translate their experiences into legal language, acceptable both on political and humanitarian grounds. Others who have no story to tell must create one, either an absurd, tear-wrenching narrative or a convincing, plausible argument. In their endeavors, many of the Czech refugees turn to the Charterists, the famous human rights movement of ' 77 for inspiration, as they think most of these dissidents are now living safely in the West. Divided as to whether these writers are heroes or traitors and thieves (WR $\left.{ }_{5} 6\right)$, the refugees nonetheless model their accounts on these forerunners' narratives and clamor for human rights. Thus, Pekárková ironically questions the language of great ideas espoused by former dissent anti-communist writers, particularly as it relates to women.

For the camp is also a gendered space, in which men outnumber women 1800 to 17 . The men in the camp, "dozens of horny lechers," lived in the "dangerous, mysterious Hilton that could envelop you with its dozens of suckers and tentacles, bring you to nirvana through its throbbing pulse" (WR 95). Moreover, the camp is visited by numerous foreign men, who come in the search of wives, offering them a foreign visa from abroad for their "services" (WR 92). The camp crackles with horror stories of women who were raped, or some who washed away all their inhibitions and just ate and ate, and had sex and more sex, or yet others, who became sex-slaves for lodgings outside the camp. In the confinement of the quarters, sex becomes public, roommates can hear couples' lovemaking, and finding a clean mattress becomes almost impossible.

Following the instructions of Nad'a, Jitka attempts to stay away from the men, yet as she does she feels gradually reduced to nothingness, as the name Nada suggests. Jitka feels increasing erotic desire, not for any man in particular but for the "male essence that had no name and every name... I wanted to populate the 
bed in private, I wanted to be populated" (WR 94). At first, she becomes attracted to men who are defined by their bodies - a Pole with burn scars (WR 57$)$ and an Afghani with a bullet wound (WR 106). These wounded men don't know what to do with her body, are not even able to successfully perform coitus interruptus (WR 109). So Jitka lives dissatisfied, with a series of short-lived one-night stands.

Then Jitka meets Mirek. She is lured to him precisely by his voice, "by the thin ribbon of his voice" (WR 128). He does not try to seduce her with his body but rather with his voice: "he wrapped [her] in his voice as if in a cloak, a silkworm cocoon in a mulberry bush" (WR 128). In this way he manages to neutralize the black hole in her soul (WR 128). Through him, Jitka feels connected to the camp itself, identifying herself as part of that community: "I suddenly felt myself touch the camp through him" (WR 141). Paradoxically, Mirek himself seemingly does not live in the camp (WR 149), as in his narratives he lives in "the boundless after and sweet before, in the bewitching elsewhere and memorable there" (150). It is through him that Jitka is also introduced to the mysterious Hilton, a male space as evident from the décor: "Pink everywhere. The boys had papered the walls, wardrobes and ceilings with naked crotches cut out of porno magazines" (WR 135). Increasingly, Jitka feels unhappy in their relationship as Mirek converses more with her body than he does with her: "and so, night after night, as soon as the lights went out, Mirek conversed with me. He conversed with my cunt, whispering sweet nothings to it... Oh yes, those two understood each other all right. Unfortunately, they left me out of the picture." (WR 153). And so it happens that Jitka is raped. Taken prisoner in the Hilton by a group of Albanians, she and another girl, Mira, are tied spread-eagle on a bed and gangraped over the course of two days. Mirek sees her there and does nothing. While on the bed, Jitka finally realizes her situation:

So I'd had the time to realize the symbolic value of the fact I was lying here, in all my glory, naked only below the waist, legs spread wide, my bare, yes, womanhood, yes that's the word, on full display... Nevertheless we were not women. We functioned here only as the female principle, as the idea of woman, like close-ups depersonified by their accessibility. We were the three-dimensional cut-outs from magazines, hung as decoration. (WR 181)

Thus, through her rape, Jitka suffers a transformation from word to flesh, where in the end she is immolated as sacrifice representing the function of womanhood as mere body. This return to the flesh is no choice; it is violence. Problematically, though, Jitka offers no resistance to it and almost even enjoys it: "And I know that my turn will come, too, but the strange thrill still will not leave me. The thrill of the hunt" (WR 178). She states that in order to ward off pain, there is little point 
in her fighting the inevitable, so she fully assumes the "function" of her womanhood:

I wince from fear and wait... beneath his touch I am conscious that I am a woman... I know perfectly well that my body happens to offer a lot - alluring curves, discoveries, surprises, which make us interesting for them... My body -

When I shut off my thoughts like a water faucet, the huddling of the man seems almost pleasant. I know that the only thing I know is I don't want pain. I don't want pain. (WR 177)

When confronted with violence, Jitka participates in her own reification - she has no alternative; she sacrifices her gendered body as well as any scream of resistance in order to survive.

After the rape, Jitka feels overwhelmed by "a sense of release: the consciousness that I was no longer in anyone's power, that I was responsible for all of my actions. It was the same feeling I experienced in Italy: you are alone with all your freedom and you don't know what to do with it... my sudden freedom lay upon me like the weight of centuries" (WR 183). Yet while seemingly reborn, Jitka at the same time realizes that "something seemed missing" (WR 183).

I suggest that Jitka's "missing link" is the one she created for herself through language: that of community. Through Mirek's words, Jitka believed to have found understanding, comfort, and security in the Other, the essentialized other. However, through her traumatic rape experience, she realizes that this sense of belonging was merely an illusion; her identity was unequivocally founded on her biologically gendered identity - her womanhood.

In The World Is Round, Pekárková thus problematizes the function of language to create community and seemingly reverts to the body as the locus of identity formation. However, she also questions the possibility of such an "embodiment." After her rape, which was seemingly "squeezed out by [her] rational mind" (WR 185), Jitka continues to be haunted by nightmares in which her body becomes language, transforming into a bell which speaks to her (WR 176). Yet the more she attempts to live alone, through her body, the more alienated she becomes:

the more I touched things, stroking rocks, cornerstones, cathedrals, tires of semis, the more I tried to do this... the more the tactile skin on my hands eroded... [I]t seemed to me that I actually left my skin on touched objects, that I was spreading the skin of my fingertips all over Europe, and through its nerves, I could still feel the pain in the distance. (WR 203)

It is erroneous to assume that Pekárková advocates a return to the body, to generate a sense of belonging or of community. In a later novel, Scarz, Pekárková describes the attempts of Božena, a woman disfigured by a similarly horrific rape, who attempts to fashion a community by allying with equally wounded people. 
One day Božena chances upon a woman like herself, a scarred, victimized woman, who bears the same wound on her cheek. For the first time, she euphorically feels that she belongs somewhere and, in her mind, in a great spirit of solidarity, she forms a gang for people like herself: the SCARZ. "For only in a gang can you do something," she explains (180). Unfortunately, Božena is brutally betrayed by this woman, and, having placed all her faith in her, loses her friends and lover in the process. She thus realizes that "for two years I have been living in that disgusting, private fissured landscape right inside my cheek. Somewhere along the way, I had stopped hiding it. On the contrary: $I$ had been hiding behind it. My face, my body, even my thoughts themselves were hidden behind this grotesque but well-known deformity" (236). Thus, for Pekárková, community, be it through language alone or through flesh alone, seems elusive. Her fiction begs the question: is community possible in today's post-communist world? If so, how to create community through the incarnation of word and/or flesh? Or are both language and body mere illusion? Can community be determined by such essential paradigms?

In all, Pekárková's work brilliantly exemplifies the process of "incarnation," that of the Word becoming flesh in a painful, violent sacrificial process. Jitka was deceived by this Word; like many in Czechoslovakia and post-communist Czechoslovakia, she believed this deception to lie in the logos of universalist discourse, in the language of human rights, or, like Božena, in the wounded union of victims in solidarity for a common cause. Nothing but words, fictions, ideological abstractions - lies. It is only when lying about to be painfully raped as a woman - that she understands her gendered identity and, from then on, her gendered body, which speaks to her, alone. Indeed, before incarnation, in totalitarianism, the Word was mysterious, intangible, invisible, and untouchable, existing beyond oppression. It is only in post-communism that the Word, liberated, became solid, real, visible, and touchable - literally pieced into the flesh. Alas, this incarnation is seemingly only possible through violence, marking the individual alone.

More importantly then, Pekárková's work questions the purpose of such incarnation in a materialist, individualist world - that of "living among us" through community. It is not a new dilemma. Kanturrková writing in communist incarceration explored the same question of how to speak in a collective voice that might be heard and heeded. What is more, it is also about the dilemma of how to act so as to be set free, not from one's material prison but from the prison of self that sets one apart from one's companions. Pekárková challenges every individual, not only those emerging from communism, to question the process and purpose of their incarnation. In all, both Pekárková and Kantůrková point to a fundamental feature of freedom in today's global economy: the burden of 
freedom. Something is missing: "You are alone with all your freedom and you don't know what to do with it."

E N D N O T ES

1 In English, see, for example, Kalivodová's "The Vision of Czech Women: One Eye Open (Gender Roles in Czech Society and Politics and Culture)," her Czech textbook "Gender životního stylu" srovnávaci úvaha in Společnost žen a mužu z aspektu gender, Praha” or Čermákovás working papers such as "Women, Work and Society," which includes the work of many Czech sociologists, such as Hana Mařiková's "The Spectre of Feminism or Feminism in Bohemia."

2 See, for example, Crompton's "Women, Employment and Feminism" or Heitlinger's "The Impact of the Transition from Communism on the Status of Women in The Czech and Slovak Republics" or her books Women's Equality, Demography, and Public Policies: A Comparative Perspective, 1993; Reproduction, Medicine, and the Socialist State, 1986; Women and State Socialism: Sex Inequality in the Soviet Union and Czechoslovakia, 1979.

3 See also Susanna Trnka, Jiřina Šmejkalová-Strickland, Jana Hradilková or Laura Busheikin's articles in Bodies Of Bread And Butter: Reconfiguring Women's Lives in the Post-Communist Czech Republic (Praha: Prague Gender Studies, 1993).

4 For «ism» loathing, see Kosatik.

5 See Mařiková's article, which offers an in depth exploration of Škvorecky's "ideology of feminine superiority" or "inside out" sexism, which would result in another form of "inverted" dominance.

6 In his 1985 "Anatomy of Containment," Havel writes "in our environment, even though women are here are much worse off than in the West, feminism seems 'dada' - involuntary funny because of the seriousness with which they stress their citizen opinion, emphasizing their harmless womanhood" (cited Vodraška, 4).

7 Under the influence of his American wife, Masaryk, as early as the 1890 s, wrote and lectured at the university on women's issues and was considered a defender of women's rights. For more on Masaryk's role in feminism, see Šiklová, "Feminism And The Roots Of Apathy In The Czech Republic."

8 Cited in Vodraška, 6.

9 Here I am referring, of course, to de Beauvoir's Second Sex, which spawned recent theory on subjectivity, such as Butler's Gender Trouble and Bodies That Matter.

10 It is in the gospel of John (1:I) that one finds the reference to the "word made flesh," later interpreted by the Church to intimate the incarnation of Jesus. Jan is the Czech form of John.

11 Unless otherwise noted, all translations from Czech texts are mine.

\section{W ORKS CITED}

Beauvoir, Simone de. The Second Sex. New York: Knopf, 1953. Boučková, Tereza. Indiánský běh. Bratislava: Fragment K, 1991.

—. Křepelice. Bratislava: Fragment, 1993. 
—. Když milujete muže. Ostrava: Středoevropské nakl., 1995.

—. Krákorám. Prague: Hynek, 1998.

Braidotti, Rosi. "Patterns of Dissonance: Women and/ in Philosophy." Feministische Philosophie. Ed. Herta Nagl-Docekal. Munich: Oldenbourgh, 1990.

Butler, Judith. Bodies That Matter: On The Discursive Limits Of "Sex." New York: Routledge, 1993.

—. Gender Trouble: Feminism And The Subversion Of Identity. New York: Routledge, 1990.

Čermáková, Marie. "Women, Work and Society." Working paper, Prague: Sociologiský Ustav, 1995.

Crompton, Rosemary. "Women, Employment and Feminism." Gender Work and Organization 4:3 (1997): $137-48$.

Havelková, Hana. "A Few Prefeminist Thoughts." Gender Politics and Post Communism. Eds. Nanette Funk and Magda Meuller. New York: Routledge, 1993. 62-73.

Heitlinger, Alena. "The Impact of the Transition from Communism on the Status of Women in the Czech and Slovak Republics." Gender Politics and Post Communism. Eds. Nanette Funk and Magda Meuller. New York: Routledge, 1993. 95-109.

-. Émigré Feminism: Transnational Perspectives. Toronto, Buffalo: University of Toronto Press, 1999.

Hercíková, Iva. Hester : aneb O čem ženy sní. Prague: Český spisovatel, 1995.

—. Rady mladému muži. Prague: Nakl. Motto, 1996.

—.Vašeñ. Prague: Nakl. Motto, 1998.

Hodrová, Daniela. Kukly : živé obrazy. Prague: Prace, 1991.

- Peruniov den : román. Prague: Hynek, 1994.

- Théta. Prague: Československý spisovatel, 1992.

Hrabik-Samal, Mary. "Ženy a neoficiálni kultura a literatura v Československu v letech 19691989." Př́tomnost' minulosti, minulost' př́tomnosti. EdS. Jolana Kusá and Petr Zojac. Bratislava, Nadácia: Milana Šimečka, 1996, 81-95.

Kantůrková, Eva. Př́telkyně z domu smutku. Cologne: Index, 1984.

—. My Companions in the Bleak House. Woodstock, N.Y.: The Overlook Press, 1987.

Kicková and Farašková. "The Emancipation of Women: A Concept that Failed." Gender Politics and Post Communism. Eds. Nanette Funk and Magda Meuller. New York: Routledge, 1993. 84-95.

Kosatík, Pavel. "Nemiluju '-ismy"' (I hate - "isms"). Feminismus devadesátých let českýma očima. Ed. Chřibková et al. Prague: Nové čtení světa, 1999.17-31.

Kriseová, Eda. Arboretum. Novinky české prózy. Prague: Československý spisovatel, 1988.

—. Klični kůstka netopýra a jiné pouidky. Toronto, Ont.: Sixty-Eight Publishers, 1982.

—. Kočiči životy : román. Prague: Hynek, 1997.

Manicom, Linzi. "Afastada Apprehensions: The Politics of Post-Exile Lovation and South Africa's Gendered Transition." Émigré Feminism: Transnational Perspectives. Toronto, Buffalo: University of Toronto Press, 1999, 30-66.

Mařiková, Hana. "The Spectre of Feminism or Feminism in Bohemia." Women Work and Society. Ed Čermákova. Working Paper 95:4. Prague: Sociologický Ustav, 1995.

Navarová, Helena. What Did Socialism Give to Women? Prague: CSAV, 1990.

Pekárková, Iva. Dej mi ty prachy. Prague: Nakl. Lidové noviny, 1996.

—. Gang zjizvených. Česka radost ; sv. 2. Prague: Matá, 1998.

—. Kulatý svět. Prague: Společnost Josefa Škvoreckého, 1993. 
—. Péra a perutě. Toronto: Sixty-Eight Publishers, 1989.

—. Truck Stop Rainbows. New York: Farrar Straus and Giroux, 1992.

—. The World Is Round. New York: Farrar Straus Giroux, 1994

Šiklová, Jiřina."McDonald's, Terminators, Coca Cola Ads, and Feminism?" Ana's Land: Sisterhood in Eastern Europe. Ed. Tanya Renne. Boulder, Colo.: Westview Press, 1997.

Šmejkalová Strickland, Jiřina. "Do Czech Women Need Feminism?" Women Studies International Forum 17.2/3 (1994): 277-82.

Věšinová-Kalivodová, Eva. "Gender životního stylu." srovnávaci úvaha in Společnost žen a mužu z aspektu gender. Prague: Open Society Fund, 1999.

-. "The Vision of Czech Women: One Eye Open (Gender Roles in Czech Society and Politics and Culture)." Dialectical Anthropology 23 (1998): 361-74.

Vodraška, Mirek. "Before the Great Exodus: The Root of Czech Antifeminism." Lecture given at Berkeley and Stanford summer 1993, translation Pavla Slaba and Anne Petrov. 